\title{
A Model of Trait and Factor Career Counseling to Enhance Students' Career Maturity in Vocational High School
}

\author{
Sudjani \\ Technology and Vocational Education \\ Universitas Pendidikan Indonesia \\ Bandung, Indonesia \\ seminar_fptkupi@yahoo.com
}

\begin{abstract}
The purpose of this study is to produce a trait and factor career counseling model to increase students' career maturity. This research method uses a combination of qualitative and quantitative (mixed methods design) include the type of exploratory mixed methods. The model of this research is a research and development using quasi experimental design with non randomly Pretest-Posttest Nonequivalent Group Design. The stages of the research and development include: (1) preliminary study, (2) model development, (3) rational model validation, and (4) empirical model validation. The sampling technique uses two stage cluster sampling, and the vocational high schools (SMK) students were selected as the research population. The result of this study shows that majority of students are in the career immature category. Factors such as family environment, community, workplace worldview, the school environment, infrastructure support, and attitudes toward conception jobs / positions provide low impact on students' career maturity. Discussion with a parent/guardian is an activity often done by the students in their effort to increase career maturity. By conducting t-test, a p-value of lower than 0,05 was obtained, meaning the trait and factor career counseling model is proven to be effective to increase students' career maturity. Based on the results above, it is recommended for guidance and counseling teachers (counselors) that career counseling model of trait and factor this into alternative options that can be implemented in schools. The school held a training for counselors to improve the competencies related to career counseling model. Researchers can then conduct research related to the level of preparedness of students and counselors to implement career counseling.
\end{abstract}

Keywords - trait and factor career counseling, career maturity

\section{INTRODUCTION}

Developments in science and technology today affects areas of the world the emergence of a new work. Field current job requires higher capabilities, rigorous and competitive. Consequently, if one does not prepare a reliable human resource will be less competitive and eventually will become unemployed. Some problems of vocational school graduates today, including: (1) lack of knowledge capabilities (potential) self, (2) have not been able to decide on plans after graduation, whether work, go to college, or the self-employed, (3) lack of understanding of the types of work, (4) have not been able to combine the potential of the work that will be chosen, and (5) have not been able to plan his career. As a result, vocational school graduates are not ready to start work as early in a career. Even if their work was not in accordance with its capabilities. Dissatisfaction in their work and tend to work rather than on their expertise. Meanwhile, a small fraction vocational graduates who continue their education to college and choose selfemployment. The implementation of career guidance and counseling in vocational aims to provide an overview and expectations will be achieved by students in the future in the world of his career. Above, demands need to develop a model of career guidance and counseling are effective. The integration between career guidance and learning programs at vocational schools will produce graduates who are ready to work and have a career maturity. One approach to career counseling aimed at improving career maturity of students is career counseling trait and factor. Vocational students choose the right career requires a good level of career maturity, because the level of career maturity affects the quality of career choice. Maturity or independence stance vocational students is maturity in choosing a career that will be a choice and a way of life in the future. Career choice is a decision making process that lasts a lifetime for those who are looking for a lot of satisfaction from his work. Career choice made at the beginning of the process of vocational development is very influential on subsequent choices, so as to establish the optimal attitude, vocational students need guidance and career counseling right.

\section{PROBLEM FormulatioN}

The problem in this research is: "Is career counseling model of trait and factor effective for improving career maturity vocational students?". In order for this research is more focused, then the detailed formulation of research problems is described as follows:

- How illustration career maturity vocational students?

- What factors that determine career maturity vocational students?

- Efforts are made to improve the students' career maturity vocational students? 
- How does career counseling hypothetical model of trait and factor for improving career maturity vocational students?

- How is the effectiveness of the model trait career counseling and career maturity factor for improving vocational students?

\section{METHODS}

In this research have been mixed methods design, because the quantitative and qualitative methods are used in an integrated and mutually supportive. This design includes exploratory mixed methods that the procedure is done using qualitative research to explore and analyze a symptom, and then collect and analyze quantitative data relating to qualitative data. This study uses the approach of research and development (research and development), in its implementation using descriptive methods, participatory methods of collaborative and experimental methods. Instrument pilot activities involving as many as 80 students were taken each 40 class XI student of SMKN 5 and SMKN6 Bandung. Furthermore, for the purposes of research hypothesis testing prior examination data requirements. Normality test results of each group of data using the formula of "One-Sample Kolmogorov-Smirnov Test" shows the distribution of scores in normal distribution. The results of the variance calculation homogeneous test data by using "Levene's Test of equality of error variances" variance showed homogenous career maturity. To determine the effectiveness of the career counseling model of trait and factor for improving students' career maturity, experimental activities have been carried out using a quasi-experimental design (quasiexperimental design) with a pretest-posttest design Nonequivalent Group Design.

\section{RESULT AND DISCUSSION}

\section{A. Preliminary Study Results}

\section{- Description of Students Career Maturity}

Student career maturity profile SMKN Engineering Program Building in Bandung in the category immature. SMK student career maturity profile shows the percentage of students who have not matured his career is greater than the percentage of students who are already mature career. The higher the percentage of students who have not done this indicate the maturity of the student's career. Furthermore, by comparing the scores aspects of career maturity of students' average scores of each aspect, obtained profiles aspects of career maturity of students, as shown in chart 1 .

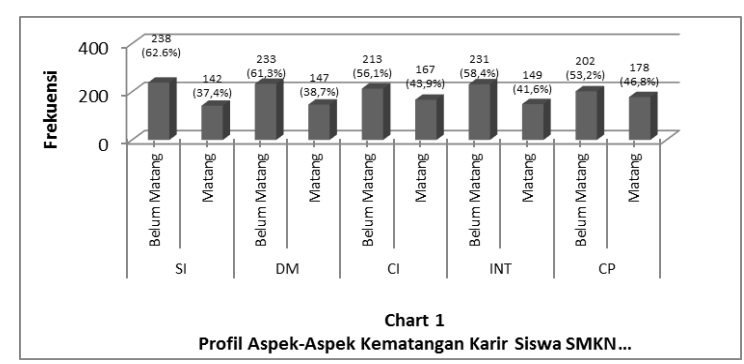

- Description Factors Affecting of Students Career Maturity
In this study the factors that influence the career maturity of students is reviewed based on six aspects, namely: (1) the environmental aspects of family and friends (LK) in the form of the involvement of parents / guardians of students in the family and friends at school, (2) the environmental aspects community residence (LM) in the form of community involvement and environmental conditions student residence, (3) aspects of insight into the world of work (WD) in the form of business students to acquire and capitalize on the insight into the world of work, (4) the environmental aspects of school (LS) in the form BK teachers and the involvement of teachers in school, (5) aspects of infrastructure support (DI) in the form of support for families, communities and schools, and (6) aspect of the attitude towards the conception of job / position (SK) in the form of employment opportunities and the perception of students. Profile of the percentage per aspect presented in chart 2.

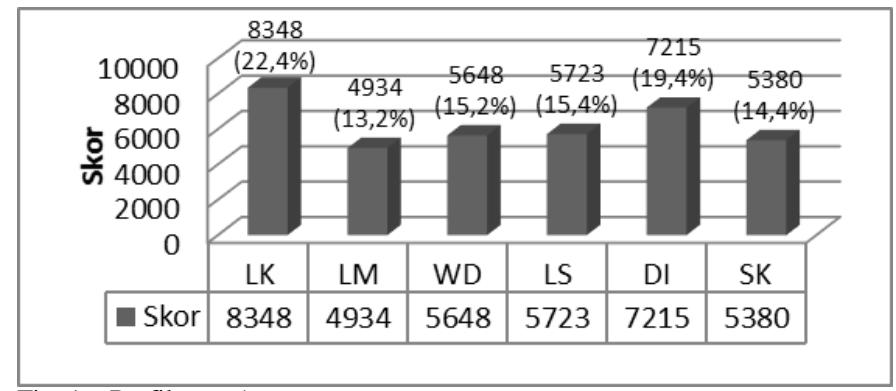

Fig. 1. Profile per Aspects

\section{- Description of Efforts Improve Students Career Maturity}

Profile efforts of students SMKN Building Engineering Program in improving career maturity in various activities shows that students most efforts made to improve career maturity during the discussions with the parents / guardians of $65.53 \%$, whereas the smallest through apprenticeship in companies / industries amounted to $32.63 \%$. Forms of activities undertaken by most students (between $50 \%$ to $60 \%$ ) are activities such as discussions with subject teachers, discussions with relatives father / mother, discussions with school friends, and pay attention to job advertisements.

\section{B. Hypothetical Model Development Career Counseling Trait and Factor to Improve Student Career MaturityUnits}

In formulating this hypothetical model, based on the results of the study of literature and the results of field studies conducted by conducting research on a small scale (preliminary study). Structure Model Hypothetical Career Counseling Trait and Factor to Improve Maturity Career Students include: (1) Rational, (2) Objectives, (3) Assumptions, (4) Target interventions, (5) Components of the model, (6) Measures models, (7) Competence counselor, (8) The structure and content of the intervention, and (9) Evaluation and indicators of success.

\section{Validation Results Field Career Counseling Model Trait and Factor to Improve Student Career Maturity}

Data calculation results of different test data pairs obtained by value $t=12.482$ and $p=0.00$. Turns count value of that is able to reject the null hypothesis (Ho) at a very significant level ( $p<0: 01)$. This means that the counselee career maturity scores in the experimental group before and after they use the model of 
career counseling trait and factor showed very different. Before the ANCOVA as a requirement, first tested whether there is any difference in the two groups pretest scores. Data from the independent t-test calculation resulted in two tests of the difference between the two groups. One test assumes that the difference between the two groups together. Levene statistic to test this assumption. The value of statistical significance is 0.280 . Therefore, this value is greater than 0.10 can be assumed that the group does not have a difference. Likewise the value $\mathrm{t}=$ 0.280 and $p=0.781$ greater than 0.05 means insignificant. This shows that there is no difference in career maturity scores in the control group with the experimental group before being given treatment and career counseling trait factor.

ANCOVA calculation results can be seen in Table 1 below.

TABLE I. CALCULATION RESULTS ANCOVA POSTTEST SCORES CAREER MATURITY EXPERIMENTAL GROUP AND CONTROL GROUP

\begin{tabular}{|l|l|l|l|l|l|}
\hline \multicolumn{1}{|c|}{ Source } & $\begin{array}{l}\text { Type III Sum } \\
\text { of Squares }\end{array}$ & df & $\begin{array}{c}\text { Mean } \\
\text { Square }\end{array}$ & F & Sig. \\
\hline $\begin{array}{l}\text { Corrected } \\
\text { Model }\end{array}$ & $904,884(\mathrm{a})$ & 3 & 301,628 & 28,178 &, 000 \\
\hline Intercept & 847,388 & 1 & 847,388 & 79,162 &, 000 \\
\hline GROUP & 136,196 & 1 & 136,196 & 12,723 &, 001 \\
\hline PRETEST & 113,445 & 1 & 113,445 & 10,598 &, 002 \\
\hline $\begin{array}{l}\text { GROUP } \\
\text { PRETEST }\end{array}$ & 55,669 & 1 & 55,669 & 5,201 &, 026 \\
\hline Error & 599,450 & 56 & 10,704 & & \\
\hline Total & 51386,000 & 60 & & & \\
\hline $\begin{array}{l}\text { Corrected } \\
\text { Total }\end{array}$ & 1504,333 & 59 & & & \\
\hline
\end{tabular}

Figures show that the calculation results in different test posttest mean score students' career maturity between the experimental group and the control group gained value $\mathrm{F}=$ 12.723. Turns $F$ value of it has been able to resist Ho is highly significant $(\mathrm{p}(0.001)<0.01)$. This means that the posttest mean score students' career maturity between the experimental group and the control group significantly different. To determine whether the student career maturity score of the experimental group and the control group was influenced by pretest scores obtained by students. Based on data calculation posttest mean score of career maturity of students, with the data pretest scores as covariates variables, the results obtained figure $\mathrm{F}=10.598$. Turns $\mathrm{F}$ value of it has been able to resist Ho is highly significant ( $\mathrm{p}(0.002)<0.01)$. This means that the posttest scores students' career maturity shown by the experimental group and the control group was not affected by pretest scores. The results of further calculations, the results of testing the interaction between the student groups (experimental and control) with pretest scores on the effectiveness of counseling received both in improving students' career maturity, the value $\mathrm{F}=5.201, \mathrm{p}=0.026<0.05$. Thus, the effectiveness of career counseling model of trait and factor for improving students' career maturity does not depend on securing their pretest scores.

\section{Discussion of Results}

Associated with low career maturity, the results of research conducted by Mc. Caffrey, Miller, and Winstoa (in Naidoo, 1998) at the junior students, seniors, and alumni there are differences in terms of career maturity. The higher the level of education the higher the career maturity owned. This indicates career maturity increases as the level of education. Ilfiandra research results (1997) to the Pasundan high school students showed a significant relationship between self-concept and career maturity, and the amount of the contribution to the career maturity of $6.25 \%$. The low student career maturity is closely related to the development of one's career. Savickas in Powell \& Luzzo (1998) describes the maturity of his career as the fit between a person's career development tasks with the stages of his age. Research results by Iqbal (2010) showed that students' career maturity is not good (low), both in terms of attitude maturity and competences maturity. Research results by Walsh and Betz in Iqbal (2010) found the maturity level of a person's career into a measuring tool to determine a person's readiness to make decisions about careers. People who have a career maturity then they have the attitude and knowledge about making career decisions. Fadhilah (2010) describes the characteristics of someone who has had a career maturity is characterized by: (1) unrealistic career choice, and (2) hesitations in making career choices.

Aspects of career maturity that most students are immature career are aspects of personal information (62.6\%). This indicates that students still do not understand the needs (needs), not understanding the roles (life roles), do not understand the values of work (work values), do not understand the interest in choosing a line of work (occupational interests), and do not know any other relevant information (other relevant information). The research result Azhar El Hami, et al. (2006) turned out $52.8 \%$ of respondents are in the category of immature and $47.2 \%$ are at a mature stage. Judging is based on aspects of career maturity acquired $52.8 \%$ of respondents are still weak in terms of planning, $53.7 \%$ of respondents do not use the information sources available to the maximum, and $43.9 \%$ of respondents have not been able to take decisions independently.

Description of the factors that influence the career maturity of students evaluated in this study include the family environment (LK), communities (LM), an insight into the world of work (WD), the school environment (LS), support infrastructure (DI), and attitudes towards conception jobs / positions (SK) showed a low percentage (below 25\%). The largest percentage found in LK factor of $24.5 \%$, while the smallest percentage contained in the LM factor of $12.1 \%$. Factors affecting the dominant student career maturity shown by LK factor compared with other factors. This means that the student's family environment where students interact with parents, siblings, and friends in the neighborhood can contribute to the maturity of his career.

Most of the students efforts are being made to increase the maturity of his career is through discussions with parents / guardians. Meanwhile, only a small fraction had discussions with the teachers' efforts guidance and counseling. This finding is surprising, because this may indicate that the role of guidance and counseling in schools has not been optimal, primarily associated with the goal of improving students' career maturity. Consistent research Iqbal (2010) shows that while career guidance has been implemented, but the results have not been able to improve self-concept and career maturity of students. Results of career guidance and counseling services according 
Syarifuddin (2010) is not optimal, in general, students do not yet have a sufficient understanding of the main characteristics of the type or pattern of personality. So they have not been able to consider their compatibility to field of work.

The trial results career counseling model of trait and factor for improving students' career maturity showed very satisfactory results, as well as career counseling indicates the effectiveness of the approach is to increase the maturity of the students after graduation vocational career. The trial results showed that the models all aspects of career maturity indicator can be increased, especially in an optimal increase occurs in the indicator of the aspects of career maturity in terms of understanding the information about yourself (Self Information / SI), which imply an awareness of the characteristics and potential is understood needs- needs in choosing a job (needs) of $53.30 \%$. Overall increase in students' career maturity ranging from $10 \%$ to $50 \%$ on all aspects of career maturity indicators studied.

\section{CONCLUSIONS AND RECOMMENDATIONS}

Conclusion the results of this study as follows: (1) most of the students in the category immature. Students immature career tend to not understand about the information themselves (self information / SI), have not been able to make a decision (decision making / DM), yet have information about a career (career information / CI), has not been able to combine personal information with career information ( integration of SI with CI / INT), and yet has a career planning (career planning), (2) Factors affecting career maturity of students show the percentage is low (below 25\%) the effect of the maturity of his career, and (3) Efforts students to increase the maturity of his career most students do activities such as discussions with parents / guardians, discussions with subject teachers and discussions with school friends, pay attention to job ads, and discussion with the brother's father / mother. In contrast, the type of student efforts directly related to the activities of career guidance and career development programs in schools, such as discussions with teachers BK and internships in companies / industries showed activity that is rarely done.

Career counseling model of trait and factor proven effective in improving all aspects of career maturity of students and increased significantly after using the trait and factor career counseling. Increased career maturity of students is highest on indicators of aspects of career maturity in terms of understanding the information about yourself (Self Information / SI), which imply an awareness of the characteristics and potential that understand the needs in choosing a job (needs). Conversely, an increase in the maturity of the smallest students' career occurred in indicators of aspects of career maturity in terms Ability to make decisions (Decision Making / DM), ie choosing the best of several alternatives.

Some research recommendations, among others: To Teacher of Guidance and Counseling / Counselor: (1) can implement a service model of career counseling trait and factor for improving career maturity of students in the school, (2) in implementing career counseling trait and factor needs to be cooperation between teacher guidance and counseling, and (3) disseminate career counseling services trait and factor since the beginning of accepted students in the school environment and are scheduled on an ongoing basis. As for the Principal Coordinator of
Guidance and Counseling Services: (1) better support student activities oriented career development of students, such as industry practices, career seminars, industrial visits, etc. and (2) to optimize the results of career counseling is needed understanding and skills related to the school counselor implementation in the classroom. This model should be disseminated through training activities and coaching to teachers' guidance and counseling in schools. For Advanced Study: (1) the need to involve demographic factors of students, such as: gender, race, ethnicity, social status, etc., (2) need to be carried out research related to the level of preparedness of students and counseling teachers / counselors to implement The career counseling, and (3) needs further research as a replication of research by developing research and the type of expertise that exist in vocational wider, so as to enhance career counseling model of trait and factor according to the changes and demands of a career in the future.

\section{REFERENCES}

[1] Aljufri, B.S. dan Kumaidi. (1991). "Kepekaan Skala Minat Kejuruan Terhadap Pengelompokan Mmurid SMTA Menurut Jenis Sekolah". Prosiding Seminar nasional Hasil Penelitian Perguruan Tinggi. Jakarta: DP3M, Dikti, Depdikbud: 169-187.

[2] Azhar, El Hami, dkk. (2006). Tingkat Kematangan Karir Pada Mahasiswa Tingkat Akhir UNPAD. Bandung: Fakultas Psikologi UNPAD

[3] Biro Pusat Statistik RI. (2009). Survey Angkatan Kerja Nasional Tahun 2007-2009. Jakarta: Pusdatinaker.

[4] Borg R. Walter, Gall Meredith D. (2003). Educational Research: An Introduction, Fifth Edition, New York: Longman

[5] Brown, Duane, et.al. (2002). Career Choice and Development: Applying Contemporary Theories to Practice. San Fransisco: Jossey-Bass Publishers.

[6] Brown, D. \& Brooks, L. (1991). Introduction to Career Development: Origins, Evaluation, and Current Approaches. San Fransisco: Jossey-Bass Publishers.

[7] Chaniago, B., (2009). Pengembangan Diri dan Soft Skill di SMK. Sumber: Pikiran Rakyat.

[8] Cresweel, J.W. (2002). Educational Research: Planning Conducting and Evaluating Quantitative and Qualitative Research. New Jersey: Merrill Prentice Hall

[9] Crites, John O. (1981). Career Counseling: Models, methods, and materials. New York: McGraw-Hill.

[10] Dahlan, S. (2002). "Inventori Pemahaman Pola Minat Jabatan: Suatu Alternatif Peranti Bimbingan Karir”. Jurnal Educandum (Edisi Oktober).

[11] __ (2005). Penggunaan Inventori Spok tuah Arahan Diri (STAD) Dalam Membantu Siswa SMA Memahami Dirinya. Ilmu Pendidikan: Jurnal Kajian Teori dan Praktek Kependidikan, (2):98-106

[12] Depdiknas. (2007). Rambu-Rambu Penyelenggaraan Bimbingan dan Konseling Pada Jalur Pendidikan Formal. Bandung: ABKIN

[13] Depnakertrans RI. (1996). Klasifikasi Jabatan Indonesia. Jakarta.

[14] Desmita. (2005). Psikologi Perkembangan. Bandung : PT. Rosda Karya.

[15] Dewa Ketut Sukardi. (2008). Pengantar Pelaksanaan Program Bimbingan dan Konseling di Sekolah. Jakarta: Rineka Cipta.

[16] Fadhilah, Siti, S. (2010). Model Bimbingan Perkembangan Untuk Meningkaqtkan Kematangan Karir Siswa. Disertasi: SPS UPI

[17] Fuhrmann, Barbara S. (1990). Adolescence, Adolescents. Second Edition. Glenview, Illinois: A Division of Scott, Foresman and Company

[18] Hiebert, Bryan. (2009). Raising the Profile of Career Guidance: Educational

[19] and Vocational Guidance Practitioner. Int J Educ Vocat Guidance (2009) 9:3-14, DOI 10.1007/s10775-008-9152-X 
[20] Holland, J.L. (1997). Making Vocational Choices: A theory of Vocational Personalities and Work Environments (3rd ed.). Odessa, Florida: Psychological Assessment Resources.

[21] Isaacson, L, E \& Brown, D.. (1997). Career Information, Career Counseling and Career Development (6th Ed). Boston : Ally \& Bacon.

[22] Iqbal, M. (2010). Model Bimbingan Perkembangan Untuk Pengembangan Konsep Diri dan Kematangan Karir Siswa Madrasyah Aliyah di Bandar Lampung. Disertasi: SPS UPI

[23] Jamaluddin, M. Syaikh, M. (2001). Psikologi Anak dan Remaja Muslin. Jakarta Timur: Pustaka Al-Kautsar

[24] Jigau, M. et al. (2007). Career Counseling: Compendium of Methods and Techniques. Bucharest: AFIR ISBN 973-7714-29-6

[25] Kasim, A. (2001). Bimbingan Konseling di Sekolah dan Perguruan Tinggi. Jakarta: Bimbingan Konseling Universitas Negeri Jakarta.

[26] Keeling, B. dan Tuck, B.F. (1979). The Validity of Holland's Occupational Typology With Male and Famale New Zealand Secondary Scholl Students. New Zealand Journal of Educational Studies, 14:50-57.

[27] Langley, R., Du Toit, R. \& Herbst, DL (1996). Manual for the Career Development Questionnaire (CDQ). Pretoria: Human Sciences Research Council.

[28] Manrihu, Mohammad Thayeb. (1986). Studi Tentang Beberapa Faktor yang Mempengaruhi Kematangan Karir Siswa di Sulawesi Selatan. Disertasi tidak Diterbitkan. Fakultas Pasca Sarjana Institut Keguruan dan Ilmu Pendidikan. Bandung.

[29] Miller, M.J. and Miller, T.A. (2005). Theoretical Application of Holland's Theory to Individual Decision-Making Style: Implications for Career Counselors. Journal of Employment Counseling. Alexandria: Mar 2005. 42, (1):20-29.

[30] Munandir. (1994). Program Bimbingan dan Konseling di Perguruan Tinggi dan Masalah Pengembangan Keterampilan Dosen Pembimbing. Makalah. Disampaikan pada Konvensi Dosen Pembimbing se Indonesia di Surakarta. UNS. Tanggal 21-23 Juli 1994

[31] Muslihudin, dkk. 2004. Bimbingan dan Konseling (Makalah). Bandung : LPMP Jawa Barat.

[32] Naidoo, A.V., Bowman, S.L. \& Gerstein, L.H. (1998). Demographics, Causality, Work Salience, and Career Maturity of African-American Student: A Causal Model. Journal of Educational Behaviour, vol 53. 1517.

[33] Osipow, SH \& Fitzgerald, LF. (2001). Theories of Career Development. Boston: Allyn and Bacon.

[34] Patton, W. \& Creed, PA (2001). Developmental Issues in Career Maturity and Career Decision Status. The Career Development Quarterly, 49(4), 336-351.

[35] Patton, W. \& Lokan, J. (2001). Prespectives on Donal's Super's Construct of Career Maturity. International for Education and Vocational Guidance, $1,31-48$.

[36] Payne and Sabaroche. (1985). Personality an Type and Occupational Preperence: Testing Holland's Theory in Caribbean. International Journal for the Advencemen of Counseling, 8(2):147-156

[37] Peterson, G.W. et al. (2007). Person Environment Congruence, Self Efficacy, and Environment Identity in Relation to Job Satisfaction: A career Decision Theory Perspective. Journal of Employment Counseling. Alexandria: Mar 2007. 44, (1):29-40.

[38] Post, A. et al. (2002). Handbook on Career Counseling: A Practical Manual for Developing, Implementating and Assessing Career Counseling Services in Higher Education Settings. Paris: UNESCO.

[39] Powel \& Luzzo, D. A. (1998). Effects of DISCOVER on the Career Maturity of Middle School Students. The Career Quarterly Vol.45, 170 172.

[40] Prayitno dan Amti. (2004). Pelayanan Bimbingan dan Konseling Sekolah Menengah Kejuruan (SMK). Jakarta : Kerjasama Koperasi Karyawan Pusgrafin dengan Penerbit Penebar Aksara.

[41] Reardon, R.C., Bullock, E.E., and Meyer, K.E. (2007). A Holland's Perspective on the U.S. Workforce from 1960 to 2000. The Career Development Qurterly. Alexandria: Mar 2007. 55, (3):262-275.
[42] Reardon, R.C. and Wright, L.K. (1999). The Case of Mady: Applying Holland's Theory and Cognitive Information Processing Theory. The Career Development Qurterly. Alexandria: Mar 1999. 47, (3):195-204.

[43] Rees, A.M. et al. (2007). Relational Personality Theory and Holland's Typology Among Women: An Exploratory Investigation. The Career Depelopment Quarterly. Alexandria: Mar 2007, 55.(3):194-206.

[44] Repetto, E. (2001). Following Super's Heritage: Evaluation of a Career Development

[45] Program in Spain. International Journal for Educational and Vocational Guidance Vol. 1, 107 - 120.

[46] Rojewski, J. W. (1994). Predicting Career Maturity Attitude in Rural Economically Disadvantaged Youth, Journal of career development, 21, 49-61.

[47] Rojewski, J. W., \& Hill, R. B. (1998). Influence of Gender and Academic Risk Behavior

[48] on Career Decision Making and Occupational Choice in Early Adolescence. Journal of Education for Students Placed at Risk, 3, 265 287.

[49] Rusmana, N. (2009). Bimbingan dan Konseling Kelompok di Sekolah (Metode, Teknik dan Aplikasi). Bandung: Penerbit Rizki Press.

[50] ___ (2009). Permainan (Game \& Play). Bandung: Penerbit Rizki Press.

[51] Salahudin, Anas. (2010). Bimbingan \& Konseling. Cet.1. Bandung: CV. Pustaka Setia,

[52] Samsudi. (2008). Daya Serap Dunia Kerja. Republika Online: Senin, 31 Maret 2008

[53] Santrock, John W.(2007). Remaja. Edisi Kesebelas. Jakarta: Penerbit Erlangga

[54] Savickas, M.L., \& Super, C.M. (1996). The Life -Span, Life-Space Approach to Careers. San Fransisco: Jossey-Bass, p.127

[55] Savickas, M. L. (2001). A Developmental Perspective on Vocational Behaviour: Career Patterns, Salience, and Themes. International Journal for Educational and Vocational Guidance Vol. 1, 49 - 57.

[56] Schmidt, John J. (2003). Counseling in Schools: Essential Service and Comprehensive Programs. Fourth Edition. Boston: Allyn and Bacon.

[57] Seligman, L. (1994). Developmental career counselling and assessment (2nd ed.). London: SAGE.

[58] Sentoadi, Fajar. (2007). Pengalaman Persiapan Pilihan Studi/Karir Mahasiswa USD Semester I Tahun Akademik 2006/2007 (studi Eksploratif-Retrospektif). Penelitian tidak diterbitkan. Yogyakarta: Universitas Sanata Darma.

[59] Sharf, Richard. (1993). Applying of counseling theories. New York: Mc. Millan.

[60] Shertzer, B. \& Stone, S.C. (1981). Career Planning Work Book: A Guide for Career Changes and for People in Career Transition. Manila: Career System.

[61] Sidiropoulou-Damakakou, dkk. (2008). Holland's Hexagonal Personality Model for a Sample of Greek University Students. International Journal Educational Vocational Guidance (8):111-125.

[62] Suherman, Uman. (2009). Konseling Karir Dalam Rentang Kehidupan. Bandung: Universitas Pendidikan Indonesia

[63] Sukardi, Dewa Ketut \& Kusmawati, Desak P.E. Nila.(2008). Proses Bimbingan dan Konseling di Sekolah. Jakarta: PT Rineka Cipta

[64] Sukmadinata, N.S. (2007). Bimbingan \& Konseling Dalam Praktek: Mengembangkan Potensi dan Kepribadian Siswa. Bandung: Maestro

[65] Sumantri M, Shaodih. (2007). Perkembangan Peserta Ddidik. Sumber: cibercounselingstain.bigforumpro.com.

[66] Suranata, K. (2009). Hubungan Antara Kesesuaian Tipe Kepribadian dan Model Lingkungan dengan Kematangan Arahan Pilihan Karir. Tesis Magister. FPS UNP Padang. Tidak Diterbitkan.

[67] Surya, M. (2003). Psikologi Konseling. Bandung: Bani Quraisy.

[68] Sutikno, A. (1996). Kualifikasi Jabatan Indonesia. Dirjen Pembinaan dan Penempatan Tenaga Kerja Depnaker RI. Jakarta: Armas Duta Jaya.

[69] Super, D.E. (1990). A life-Span, life-Space Approach. Career Choice and Development. In Brown, D. \& Brooks, L. San Fransisco: Jossey-Bass Publishers. 
[70] West. (1988). Comparison of Career Maturity and Its Relationship with Academic Performance. Journal of American Indian Education

[71] Williamson, E. G. (1939). How to Counsel Students. New York: McGraw-Hill

[72] Winkel, W.S \& Sri Hastuti. (2006). Bimbingan dan Konseling di Institusi Pendidikan. Jakarta: PT. Grasindo.

[73] (2010). Bimbingan dan Konseling di Institusi Pendidikan. Jakarta: PT. Grasindo
[74] Winkel, W.S. (1997). Bimbingan dan Konseling di Institusi Pendidikan. Jakarta: PT. Grasindo.

[75] Yusuf, L.N., S. (2006). Psikologi Perkembangan Anak dan Remaja. Bandung: PT. Remaja Rosdakarya

[76] Yusuf, S. dan Nurihsan, J. (2008). Landasan Bimbingan dan Konseling. Bandung: PT. Remaja Rosdakarya. 